УДК 621.391.7: 004.934.2

\title{
ОЦЕНИВАНИЕ СПЕКТРА ПОЗДНЕЙ РЕВЕРБЕРАЦИИ: ОПТИМИЗАЦИЯ ПАРАМЕТРОВ
}

\author{
ПРОДЕУС А. Н., ОВСЯНИК В. П.
}

\author{
Национальный технический университет Украины \\ «Киевский политехнический институт», Украина, \\ Киев, 03056, пр-т Победы 37
}

\begin{abstract}
Аннотация. Коррекция речевых сигналов, искаженных реверберацией, актуальна при построении систем связи, систем автоматического распознавания речи, слуховых аппаратов. При подавлении поздней реверберации методом спектрального вычитания или методом частотной коррекции необходимо оценивать спектр поздней реверберации. Несмотря на то, что процедура такого оценивания в основном разработана, существует ряд неясных моментов, связанных с ее оптимизацией. В данной работе, с использованием методов компьютерного моделирования выработаны рекомендации, позволяющие оптимизировать оценивание спектра поздней реверберации по таким критериям как качество речевого сигнала и точность автоматического распознавания речи
\end{abstract}

Ключевые слова: подавление поздней реверберации; спектр поздней реверберации; автоматическое распознавание речи; качество речевого сигнала

\section{ВВЕДЕНИЕ}

Речевой сигнал в помещениях практически всегда подвергается искажающему действию реверберации, что приводит к существенному ухудшению качества и разборчивости речи в системах связи, в слуховых аппаратах, отрицательно сказывается на эффективности систем автоматического распознавания речи (APP) [1-4]. В [5] предложено подавлять позднюю реверберацию методом спектрального вычитания, предварительно оценивая спектр мощности поздней реверберации. В [6] показана возможность подавления поздней реверберации с использованием метода частотной коррекции.

К сожалению, полученные в $[5,6]$ результаты носят предварительный характер, поскольку параметры оценки спектра поздней реверберации не оптимизированы. В [7] поло- жено начало устранению этого недостатка и показано существование границы между ранними отражениями и поздней реверберацией, оптимальной в смысле таких критериев как качество речевого сигнала и точность автоматического распознавания речи. Цель данной работы состоит в уточнении результатов [7], а также в выработке новых рекомендаций по оптимизации оценки спектра поздней реверберации.

\section{ПОСТАНОВКА ЗАДАЧИ}

Модель речевого сигнала $y(t)$, искаженного реверберацией, возможно представить в виде свертки «чистого» речевого сигнала $x(t) \mathrm{c}$ импульсной характеристикой $h(t)$ помещения:

$$
y(t)=\int_{0}^{\infty} h(v) x(t-v) \mathrm{d} v=x(t) \otimes h(t),
$$

